\title{
Seguridad del paciente y su percepción en los profesionales de la salud ${ }^{1}$ \\ Patient safety and its perception in health professionals
}

Recibido: 29 de agosto de 2016 - Revisado: 13 de diciembre de 2016 - Aceptado: 16 de marzo de 2017.

Cielo Rebeca Martínez Reyes ${ }^{2}$

Jennifer Agudelo Durango ${ }^{3}$

Sandra Milena Areiza Correa ${ }^{4}$

Diana Marcela Giraldo Palacio ${ }^{5}$

\section{Resumen}

Este artículo determina la percepción de la cultur. de : ridad del paciente en el personal de enfermería de cuatro institurinnes de prı $r$ - y sę «ndo nivel de atención, en convenio con la Corporación Uni ersita i Advent sta, durante el segundo semestre de 2015. Allí participaron profesı ales auxiliare de enfermería que cumplían con criterios de inclusión. I us dato a lu mediante la Hospital Survey on Patient. Se encontró a la cultur de seguridad en enfermería se construye con acciones pequeñas y cot anas que $\mathrm{f}$ den llegar a salvar la vida del paciente. Fomentarla y con vidarla requ ee de equilibrio entre la dotación de personal y las tareas asignad? $\_$en jornadas labo 'os justas, aspectos que sumados a la educación y al empoderam. to de a gerencia en el tema, propiciarán un ambiente de confianza y aprendizaje orga acional.

P abras ave

Cuı. $\neg, \quad$ r ridad deı paciente, cuidado de enfermería.

\section{Abstrac}

This artic _ determine nursing staff perceptions towards the patient safety culture in four institutions of first and second level of care, in agreement with the Corporación Universitaria Adventista during the second semester of 2015. The participants were the professionals and nursing assistants who met the criteria of inclusion and participated voluntarily. Data were collected through the Spanish version of the Hospital Survey on Patient. Founded that safety culture on nursing it is building with little and daily actions that can save the patient's life. Foment and consolidate it requires a balance between staffing and tasks assigned in workdays, aspects that, added to education and the empowerment of management in the field, will foster an atmosphere of trust and organizational learning.

\section{Keywords}

Culture, patient safety, nursing care.

\footnotetext{
Artículo de reflexión derivado del macroproyecto en el que se indagó sobre la cultura de seguridad del paciente en el personal de enfermería de instituciones de I, II, III y IV nivel de atención de Antioquia en convenio con la Corporación Universitaria Adventista.

${ }^{2}$ Corporación Universitaria Adventista, Medellín, Colombia. Correo electrónico: cielorebe26@hotmail.com

${ }^{3}$ Corporación Universitaria Adventista, Medellín, Colombia. Correo electrónico: jeniffer3281@hotmail.com

4 Corporación Universitaria Adventista, Medellín, Colombia. Correo electrónico: sareiza@unac.edu.co

5 Corporación Universitaria Adventista, Medellín, Colombia. Correo electrónico:dmgiraldo@unac.edu.co

Para citar este artículo use: Martínez, C., Agudelo, J., Areiza, S., y Giraldo, D. (2017). Seguridad del paciente y su percepción en los profesionales de la salud. Civilizar Ciencias Sociales y Humanas, 17(33), 277-292.
} 